\title{
Problems and Ways of Promoting Innovation and Entrepreneurship Education against the Background of "New Normality"
}

\author{
Xinhong Wang, Tingting Li \\ School of Management, Xi'an University of Science and Technology, Xi'an, Shaanxi 710054, China.
}

826812444@qq.com

Keywords: Innovation and entrepreneurship education, new normality, problem, way.

\begin{abstract}
With the economic development of our country entering the "new normality", under the background of the country vigorously promoting the construction of innovative country, it is an important aspect of the current university education reform to promote college students' innovation and entrepreneurship education and start a business to drive employment. The innovative entrepreneurship education in colleges and universities is facing the problems of educational concept, curriculum system, practical platform, teachers' strength and so on. Colleges and universities should draw up practical and feasible plans for innovative entrepreneurship education, actively explore the strategies and approaches conducive to the development of innovative entrepreneurship education for college students, and establish a multi-level system of innovative entrepreneurship education for college students. In the end, colleges and universities are encouraged to stimulate students' interest and potential, and to cultivate more innovative entrepreneurial talents for the country and society.
\end{abstract}

\section{Introduction}

Since the 21st century, innovative and entrepreneurial education has become a major strategic measure for countries all over the world to promote scientific and technological progress and economic prosperity. It has even been hailed by UNESCO as the "third passport" for learning. In recent years, our country pays more and more attention to innovative entrepreneurship education, which plays an important role in the cultivation of innovative entrepreneurship, the relief of employment pressure and the implementation of innovation-driven strategy. However, innovation and entrepreneurship education in colleges and universities in China is still in the primary stage, and there are still some problems objectively. For example, in some local governments' education departments and colleges, the knowledge of innovation and entrepreneurship education is insufficient, the combination of concept and practice is not enough, the teaching methods and methods are single, and the target training is not strong. At present, the economic development of our country has entered the "new normality", and it has become an inevitable trend to improve the ability of independent innovation and to promote the adjustment of economic structure and the upgrading of industry by innovation. The 19 party put forward the slogan of "encouraging multi-channel and multi form employment while promoting entrepreneurship and promoting employment". Under the macro background of promoting the "four comprehensive" strategic layout and pushing the "China made in 2025"strategy coordinated by the state, the reform of higher education has been deepened and some important "new normality" has been presented. For example, our country presents the connotation development with the quality promotion as the core, the release of school vitality in the reform and innovation, the deep opening of the University and the guidance of educational science and technology. It is an important measure for colleges and universities to reform and develop themselves and improve the quality of talent training by vigorously promoting the innovative entrepreneurship education of college students and actively exploring the construction of innovative entrepreneurship education system.

Therefore, based on the background of the "new normal" of economy, this paper probes into the existing problems and the ways to promote the innovation and entrepreneurship education in colleges and universities in China. 


\section{The Necessity of Carrying out Innovative and Pioneering Education in Colleges and Universities}

\subsection{Strategic Needs for Building Innovative Countries.}

Colleges and Universities are an important force in implementing the national strategy of independent innovation and building an innovative country. They should give full play to their own functions, constantly enhance their independent innovation ability, change their ideas of development, implement innovative entrepreneurship education, set up an innovative entrepreneurship education platform, focus on training innovative talents with innovative entrepreneurial consciousness and capability, and provide multi - faceted services and support for the construction of innovative countries.

\subsection{Urgent Need for Transformation and Development of Applied Undergraduate Colleges and} Universities.

Under the guidance of the Ministry of Education, most local colleges and universities begin to transform into applied science and technology universities, and actively explore and practice the road of construction of China's universities of applied science and technology. The innovation and entrepreneurship education of college students is an important breakthrough in the transformation and development of applied undergraduate colleges and universities. It is the main content of the transformation and promotion of the characteristic development of the school and the reform of the training mode of innovative talents.

\subsection{Objective Needs of University Students' Self-development.}

Nowadays, the demand for talents in the society is constantly improving, and innovation and entrepreneurship education pays attention to the improvement of students' comprehensive quality of innovation and entrepreneurship, especially the expansion of the operational ability of experiment and practice. This requires not only the application of theoretical teaching, but also practical teaching, so as to cultivate students' ability to find and solve problems independently and autonomously with creative thinking. Students in the school study stage is the key stage to cultivate innovative entrepreneurial ability. The school should constantly guide them to set up innovative entrepreneurial awareness, integrate professional knowledge and skills into innovative entrepreneurship education, enlighten thinking, stimulate interest, and be brave to practice. At the same time, the school should also pay attention to the cultivation of students' dual identity, that is, not only job seekers, but also job creators.

\section{Problems of Innovation and Entrepreneurship Education in Colleges and Universities under "New Normality"}

\subsection{The Consciousness of Innovation and Entrepreneurship is Weak, and the Idea is Vague.}

The weak awareness of innovation and entrepreneurship is mainly due to the fact that the traditional cultural concept and educational system have restricted the cultivation of college students' entrepreneurial awareness and entrepreneurial ability for a long time. Most of the college students who are trained under the traditional education system in our country tend to choose to go to higher education when they graduate, take the examination of civil servants, institutions or study abroad, and choose to avoid the relatively high risk of starting a business. The understanding of entrepreneurship education among college students is one-sided and superficial. Some students who do not have entrepreneurial intention think that innovative entrepreneurship education has nothing to do with them, and they do not realize the value and significance of innovative entrepreneurship education for personal comprehensive literacy improvement.

The idea of innovative entrepreneurship education is vague. Some scholars regard innovative entrepreneurship education as teaching students how to set up enterprises. The innovation and entrepreneurship education pays much attention to the education class, the training of entrepreneurial skills and the imparting of entrepreneurial knowledge. Some other scholars believe that the purpose of innovative entrepreneurship education is to create jobs through entrepreneurship, promote 
employment through entrepreneurship, and solve employment problems through entrepreneurship. They focus on the proportion of college students' entrepreneurship and the number of successes, the number of people employed by the entrepreneurs, and the scale of the entrepreneurial base. They want to strengthen entrepreneurship training in the short term to create a group of entrepreneurial elites, equate innovative entrepreneurship education with "entrepreneurial skills" training, and use the success rate of entrepreneurship as the "touchstone" for innovative entrepreneurship education. It ignores the role of innovative entrepreneurship education in personal growth and cultivation of innovative entrepreneurship.

The traditional culture of our country has always advocated "everything is inferior, only reading is high". Even under the background of advocating "mass entrepreneurship, mass innovation", the social support for college students' entrepreneurial activities is also low. Although colleges and universities strongly advocate the development of entrepreneurship, but the depth and breadth of entrepreneurial atmosphere still need to be expanded. At present, our state of development at the economic, social and university levels is not enough to fully support the practical needs of innovative entrepreneurship education. We need a buffer and adjustment period to adjust the social employment expectations, change the concept of employment entrepreneurship of college students, enhance the employment entrepreneurship literacy of college students and expand the inclusive ability of the market.

\subsection{The Educational Resources are Scarce, and the Training System is Not Comprehensive.}

Innovation and entrepreneurship education lack of localized quality teaching materials. In our country, when we learn from and use foreign teaching materials or cases, there is a phenomenon of direct transplantation. The contents and forms of the imported innovative entrepreneurship education are lack of digestion and absorption. Innovative entrepreneurship education teachers lack systematic basic theoretical knowledge and professional training. They have very little experience working or starting a business, and their overall specialization is low. Although the education department and the university organize the training of teachers each year, the number of participants is negligible with respect to the large entrepreneurial group, which is far from meeting the requirements of the university to carry out innovation and entrepreneurship education.

At present, entrepreneurship education has not been fully integrated into the national discipline construction system. As the main implementing body of innovative entrepreneurship education, colleges and universities mainly rely on the teachers and teaching conditions of other disciplines to carry out innovative entrepreneurship education at present. The concept of innovation and entrepreneurship education has not yet been reflected in all aspects of school development, discipline construction, teaching management and evaluation. Innovation and entrepreneurship education still carries out teaching activities according to the traditional teaching mode, which leads to its lack of discipline independence, pertinence and systematicness. Although some schools have brought the innovation and entrepreneurship education into the school curriculum system, most of them are employed as employment guidance and a curriculum module of career planning. It has not yet formed a complete discipline system, and the training objectives and teaching objectives are vague.

\subsection{The Guarantee System of Innovation and Entrepreneurship Education is Not Sound.}

The Social atmosphere and the overall environment of innovative entrepreneurship education need to be further improved. At present, most of the innovative and entrepreneurial education is a monologue for colleges and universities, they lack the whole society's overall force to escort them, which is mainly reflected in the following aspects. First, the current conditions of universities are not conducive to the development of innovative entrepreneurship education, such as most schools have not really established a system, the implementation of the national innovative entrepreneurship education policies and related provisions are not in place, innovative entrepreneurship education teachers are weak, the atmosphere of innovative entrepreneurship education is not strong, the equipment and soft environment are not perfect, these are the obstacles that colleges and universities face in carrying out innovative entrepreneurship education. Second, in recent years, the government has issued a series of preferential policies to encourage college students to innovate and start their own businesses, but these policies need systematic thinking and concrete implementation. Innovation 
and entrepreneurship education is a systematic project involving multiple disciplines. It requires the joint efforts of all sectors of society to respond. In addition, the service awareness of government agencies is weak, the depth and breadth of policy advocacy is insufficient, and the initiative of the service needs to be strengthened. Third, society, enterprises and the corresponding institutions have not fully interpreted and implemented the entrepreneurial policies issued by the government. They lack positive feedback and support for innovation and entrepreneurship education in colleges and universities.

\section{The Effective Way to Promote the Innovation and Entrepreneurship Education in Colleges and Universities under the "New Normal"}

Independent entrepreneurship is not only challenging and high elimination rate, but also requires solid professional knowledge and skills, especially endurance and resilience to withstand failures and setbacks. This requires university education to integrate the innovative and entrepreneurial education into the whole education system, implement and run through the whole process of student training, and carry out the "five party linkage".

\subsection{Construction of Teaching Materials.}

Textbooks are the basis of the curriculum. In order to achieve entrepreneurship education for the quality and skills of college students, we must first promote the construction of teaching materials. At present, the biggest problem of innovation and entrepreneurship education in China lies in the lack of teaching materials with Chinese local characteristics. Many of the translated foreign textbooks do not have local characteristics, which cannot meet the needs of Chinese social innovation and entrepreneurship. Therefore, we must promote the construction of innovative and entrepreneurial teaching materials. On the basis of the latest and mature achievements of foreign countries, we should build up a textbook system which meets the national conditions of China, has Chinese style and meets the needs of China's entrepreneurship.

\subsection{Professional Education.}

The course of entrepreneurship education is not only the foundation of entrepreneurship education, but also the most indispensable knowledge preparation for entrepreneurship education. Therefore, I must combine professional education with discipline infiltration. Compared with foreign universities, many colleges and universities in China lack professional courses in entrepreneurship education, which reflects that the construction of entrepreneurship courses in China is not perfect. Therefore, it is necessary to concretely embody or increase professional courses through innovation or entrepreneurship courses. It can be said that the standardization of entrepreneurship education curriculum can promote the reserve of entrepreneurial knowledge and the cultivation of entrepreneurial skills of college students, which is also the purpose of innovative entrepreneurship education.

\subsection{Teacher Training.}

In order to achieve good entrepreneurial education effect, colleges and universities must have an excellent faculty. In the current shortage of entrepreneurial teachers, the rational allocation of part-time teachers is an ideal choice. College students should be provided with research and empirical guidance teachers, so that they can further improve their entrepreneurial qualities. The teachers of entrepreneurship education should also be divided into theoretical education and practical education. On the basis of ensuring that students can acquire full and innovative knowledge of entrepreneurship, they should also let students put their innovative knowledge and professional skills into practice, which requires that teachers not only be good at excavating the students' talent for entrepreneurship, but also have strong practical teaching ability.

\subsection{Capital Equipment.}

For the college students, the biggest difficulty is the lack of equipment and funds, which requires that the university should establish a long-term cooperative mechanism with the large and medium enterprises related to the students' entrepreneurial entry, so that the students with the quality of entrepreneurship can be created under the guidance and help of the large and medium-sized 
enterprises. The government and universities should provide support and convenience for college students, and continue to use a series of incentives, such as tax and fee reduction, low interest loans, and other encouraging policies to promote and standardize college students' independent entrepreneurship.

\subsection{Practice Platform.}

Colleges and universities should provide a practical platform for university students to start their own businesses, so as to create an atmosphere to encourage students to innovate and start businesses. Colleges and universities should analyze the advantages and disadvantages of students with entrepreneurial motivation, reduce the practical difficulty and build a good social environment and public opinion guidance for college students to innovate and start their own businesses. It can provide convenient conditions for university students to create property right protection and transaction through online and offline cooperation. There is no doubt that building a practical platform for college students' entrepreneurship is an important way to cultivate college students' innovative entrepreneurial ability and thinking, as well as an important way to enhance the nation's overall innovation capability.

\section{References}

[1]. Liang Kunlun. Under the new normal situation of innovation and entrepreneurship education in Colleges and universities and innovation [J]. Journal of Haunches Science and Technology College. 2015, (06), p.116-118.

[2]. Cheng Li. Under the new economic norm on innovation and entrepreneurship education reform [J]. Journal of Nanjing University of Finances and Economics. 2015, (05), p.104-108.

[3]. Chen Wei, Li Jingo. Innovation and entrepreneurship education in Colleges and Universities under the new economic normal thinking [J]. Social scientists.2016, (04), p.135-138.

[4]. Bai Longjun. On the issue of innovation and entrepreneurship education in Colleges and Universities under the new normal [J]. Continuing education research. 2016, (08), p.13-15.

[5]. Yuan Hinging. Some education of College Students' innovation and entrepreneurship on [J]. Chinese adult education. 2016, (11), p. 25-28.

[6]. Shu Yang. The innovation of Higher Vocational entrepreneurship education under the new normal practical difficulties, causes and path [J]. Occupation technology education. 2016 (29), p. 49-53.

[7]. Wu Hai. To carry out the education of creation and innovation of college students and Countermeasures under the new normal [J]. Journal of North Central University. 2016, (05), p. 60-63.

[8]. Wang Jihadi. Under the background of the new normal college students' innovation and entrepreneurship education [J]. Experimental technology and management. 2016, (08), p. 217-224. 